Int. J. Morphol.,

27(1):239-244, 2009.

\title{
Toxicity of Sucralose in Humans: A Review
}

\author{
Toxicidad de la Sucralosa en Humanos: Una Revisión
}

"Ademir Barianni Rodero; **Lucas de Souza Rodero \& *** Reinaldo Azoubel

RODERO, A. B.; RODERO, L. S. \& AZOUBEL, R. Toxicity of sucralose in humans: a review. Int. J. Morphol., 27(1):239-244, 2009.

SUMMARY: Sucralose is a non-nutritive artificial sweetener, 600 times sweeter than sucrose, and is very stable at high temperatures, among other characteristics. It was approved by the FDA, in 1999, to be utilized in foods, beverages, pharmaceutical products, diets and vitamin supplements. Studies suggest a diffusion, through the placental barrier, of small doses of sucralose and its metabolites. Its hydrolysis products (4-CG e 1,6-DCF) are more rapidly absorbed than sucralose: 4-CG is excreted intact in the urine, and 1,6-DCF undergoes reduction with elimination by the urine or rapid conjugation with glutathione. Various organs can be affected by ingestion of high doses of sucralose. As a result of the rise in global consumption of sweeteners and light- or diet-type products, studies are necessary to evaluate the action of this substance in the human species. The present study aims to accomplish a review of the literature that involves its indications of use, pharmacodynamics as well as the carcinogenic, teratogenic, neurotoxic, and nephrotoxic potentials of sucralose.

KEY WORDS: Sucralose; Sweetener; Toxicology.

\section{INTRODUCTION}

Sucralose is an edulcorant obtained from sucrose where three hydroxilic groups, from positions 4,1 and 6 are replaced by 3 chlorine atoms to form the compound 4,1',6' trichlorogalactosacarose, also known as 1, 6 -dichloro-1, 6 -dideoxy - b-Dfructofuranosyl-4 - chloro $-4-\operatorname{deoxy}-\mathrm{a}-\mathrm{D}-$ galactopyranoside, often abbreviated in chemical nomenclature as 4,1', 6'-triclorogalactosacarose or 4,1', 6' - trichloro - 4,1', 6'-trideoxi-galacto-sucrose (Knight, 1994).

Sucralose was discovered accidentally in 1976 by Shashikant Phadnis, a student who had graduated from King's College in the UK. Phadnis took part in a team with researchers from Queen Elizabeth College, at the University of London, who were seeking to synthesize halogenated sugars. During one part of the experiment, due to difficulty in interpreting English, he erroneously executed a task, chlorinating the sugar, he tasted it instead (Ophardt, 2003) (Fig. 1).

In 1989, the scientists Leslie Hough and Khan,

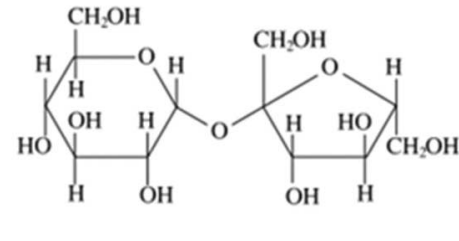

Sucrose

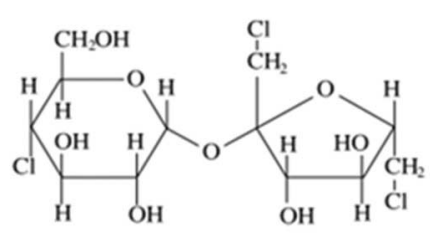

Sucralose
Fig. 1. Sucrose and sucralose structures.

in turn, evaluated the different effects of sweeteners derived from sucrose, when it was found to be linked with determinate halogens (Frank, 2002).

Studies indicate the existence of 2 hydrolysis products of sucralose, 4-CG and 1,6- DCF, and that these products are more rapidly absorbed after oral administration than the original sucralose compound. The hydrolysis product $4-\mathrm{CG}$ is excreted, essentially in intact form, in the urine, while 1,6-DCF follows one of two principal metabolic pathways: reduction to 1,6 dichloroaminnitol, rapidly excreted in unaltered form in the urine, or conjugated with glutathione (Grice \& Goldsmith, 2000) (Fig. 2).

\footnotetext{
* Unicastelo-Universidade Camilo Castelo Branco, University, School of Health Sciences - Fernandópolis, SP, Brazil.

** Unifoa - Centro Universitário Volta Redonda. School of Health Sciences - Volta Redonda - RJ. Fernandópolis - SP, Brazil.

${ }^{* * * *}$ Post-Graduate Program in Health Sciences-School of Medicine at São José do Rio Preto - SP. São José do Rio Preto - SP, Brazil.
} 


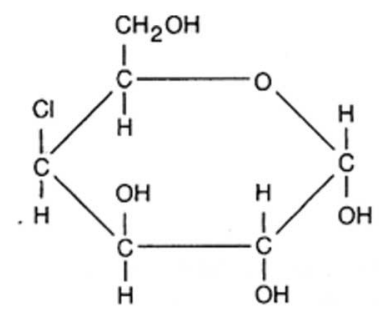

4-CG

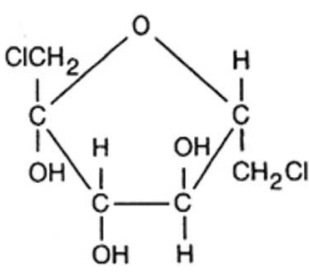

$1,6-\mathrm{DCF}$
Fig. 2. Hydrolysis products of sucralose: 4-chloro-4-deoxy-Dgalactose (4-CG) and 1,6-dichloro-1-6-dideoxy-D-fructose (1,6DCG).

Indications of use. Sucralose consumption has increased by possessing the following sweetener characteristics: noncaloric, insipid, stable at high temperatures and in acidic medium, and not being hydrolyzed even during digestion or metabolism by virtue of the extreme stability of its carbon-chlorine bonds (Binns, 2003; Barndt \& Jackson, 1990), and being hydrophilic, with $25 \%$ solubility (Grice \& Goldsmith). According to Binns, it presents the important characteristic of not interacting chemically with other foods, being stable in the presence of ethanol and able to be stored for more than one year while maintaining $99 \%$ of its original flavor. Its characteristics are preserved, even during pasteurization, sterilization and cooking at high temperatures (Knight).

Another characteristic of sucralose is non-interference in the utilization and absorption of glucose, metabolism of carbohydrates and secretion of insulin. Therefore, it is a safe substance able to be ingested by diabetes patients (Campos, 2000), and neither stimulates insulin secretion nor reduces plasma glucose concentration (Candido \& Campos, 1995). Furthermore, clinical studies concluded that sucralose is neither acidogenic nor cariogenic (Mandel \& Grotz, 2002).

At the beginning of 1998, the Food and Drug Administration (FDA), after evaluating 110 studies in animals and humans, approved sucralose as a food additive in 15 varieties of foods and beverages (Whitmore, 1998). In 1999, this approval was extended to its utilization as a sweetener for general use in all foods, conventional beverages, dietetic vitamin supplements, medical diets, such as cooked and baked foods (Department of Health and Human Services, 1999; McNeil Nutritionals, 2006).

Based on its thermic properties, stability over wide $\mathrm{pH}$ variations, lack of chemical interaction with ingredients and its solubility - sucralose can be used as a table sweetener in dry formulations (such as, powdered drinks and instant desserts), in flavorings, preservatives, seasonings, ready sauces, jams, syrups, breads, dairy desserts, canned vegetables, pasteurized products and other foods (Campos, 2000, 2002). Currently, according to MacNeil, its use is permitted in more than 80 countries and it is present in over three thousand products (McNeil Nutritionals). In Brazil it is found in the formulation of more than 500 products and, globally, consumed by thousands of persons (Pachione, 2003).

Pharmacodynamics. In humans the oral administration of sucralose, at the dose of $1 \mathrm{mg} / \mathrm{kg}$ body weight per day, shows that the digestive tube is the major route of elimination, with an average of $78.3 \%$ (69.4 to $89.6 \%$ ), while urine eliminates a mean of $14.5 \%$ (8.9 to $21.8 \%$ ) of this dose. Variations depend on individual differences in absorption and excretion. Even with administration of high doses, there was no corresponding increase in the average urinary elimination, suggesting the possibility of reduction in sucralose absorption (Roberts et al., 2000).

When sucralose is administered venously to rats at a dose of 2 to $20 \mathrm{mg} / \mathrm{kg}$ body weight, it is excreted at the proportion of approximately $80 \%$ by the urine and $9 \%$ to $16 \%$ through the feces; however, when administered orally at doses from 10 to $1000 \mathrm{mg} / \mathrm{kg}$, urinary excretion is below $5 \%$, showing that sucralose is poorly absorbed in the intestinal tract, and is almost entirely excreted in unaltered form through the feces, rapidly in the first 24 hours, independent of dose and the sex of the animals (Sims et al., 2000).

John et al. (2000), employing oral administration, detected in non-pregnant rabbits, sucralose excretion of $22 \%$ by urine and 55\% via feces. In pregnant rabbits excretion was $22 \%$ urinary and $65 \%$ through the gastrointestinal tract. The same authors, investigating the excretion and metabolism of sucralose in mice through both oral and intravenous administration, found that when receiving $20 \mathrm{mg} / \mathrm{kg}$ body weight/day intravenously, the preferential excretion route was urinary, being almost $80 \%$ in 5 days, while fecal elimination was $22 \%$ of the dose. With oral administration at doses of 1000,1500 and $3000 \mathrm{mg} / \mathrm{kg}$ body weight/day, urinary elimination averaged, respectively $23 \%, 15 \%$ and $16 \%$, indicating that 20 to $30 \%$ of this oral dose is absorbed. This study shows that, even with augmented administration of sucralose, there is no corresponding rise in absorption or consequent renal elimination. Sucralose was excreted in unaltered form, and represented more than $80 \%$ to $90 \%$ in the urine and feces.

When administered orally to dogs, sucralose is rapidly absorbed, with urinary excretion in inactive form, with conjugated glucuronic acid being present with the sucralose, 
at small doses, in proportions of $2 \%$ to $8 \%$ of the dose administered. In intravenous administration, unaltered urinary excretion of sucralose predominates, with glucuronic acid detected, conjugated with sucralose, in $15 \%$ to $20 \%$ of the dose administered (Wood et al., 2000).

According to some studies, the elimination profile in humans is similar to the profiles found in rats, dogs and mice, although urinary excretion in rats is half that observed in humans, while elimination by the feces is higher in those animals (Roberts et al.; Sham, 2005). Pharmacokinetic studies concluded that $85 \%$ of sucralose is not absorbed, and is excreted intact in the feces, with absorption limits of approximately $15 \%$ of the dose consumed by passive diffusion.

\section{DISCUSSION}

The ADI (Acceptable Daily Ingestion) of sucralose in humans is $15 \mathrm{mg} / \mathrm{kg}$ body weight/day (Goldsmith \& Meckel, 2001). Based on the studies of MacNeil (McNeil Specialty Products, 1987) reporting the diffusion of sucralose or of its metabolites through the placental barrier, investigations were accomplished to evaluate its possible teratogenic effects at diverse doses and by different routes of administration.

Teratological studies of rodent organogenesis (in pregnant rats), from the $6^{\text {th }}$ to $15^{\text {th }}$ day of gestation, at doses of 500,1000 and $2000 \mathrm{mg} / \mathrm{kg}$ body weight/day, and in nonrodents (pregnant rabbits), from days 6 to 19 of gestation, at doses of 175,350 and $700 \mathrm{mg} / \mathrm{kg}$ body weight/day), did not detect alterations in fetal development, confirmed after necropsy. There was only a slight increase in water consumption and intestinal disturbances in female rabbits (Kille et al., 2000).

According to a review by Grice \& Godsmith, animals were treated with an equimolar mixture of hydrolyzed products of sucralose, demonstrating that, although a focal increase occurs in the incidence of clear cells in the liver, there is no significant evidence of progression of this lesion to neoplasia, when compared to the non-treated group. Studies on sucralose and its hydrolysis products, did not reveal significant hematological alterations: the number of lymphocytes appeared to have diminished in treated dogs. In rats, sucralose alterations of 2.5 and $5 \%$ do not constitute toxicity and would be secondary to diminution of food consumption, by decreasing palatability. Studies in rats indicated an adverse effect of sucralose on the immune system.
Two-year carcinogenesis studies of mice even detected a rise in the incidence of chronic nephropathy, compared to the control group, but showed statistical significance only in female rats of the group treated with a high dose of sucralose. However, no increase was observed in other renal pathologies in rats, dogs or primates that had been fed the same diet. Works on oncogenesis showed higher incidence of pelvic mineralization, accompanied by epithelial hyperplasia of the renal pelvis, in female rats submitted to treatment with doses containing 1 to $3 \%$ sucralose (Lord \& Newberne, 1990). In relation to reproduction, studies in female rabbits and rats with sucralose and female rats with sucralose hydrolysis products yielded no evidence of a teratogenic effect nor alteration of reproductive capacity. In studies of female rats using sucralose hydrolysis products at high doses $(250 \mathrm{mg} / \mathrm{kg}$ body weight $)$ there are multiple pieces of evidence of maternal toxicity. Progeny showed little change in development, but this dose is 40,000 times the maximum value permitted in the USA $(6.6 \mu \mathrm{g} / \mathrm{kg}$ body weight/day). However, general toxological studies, conducted with sucralose and its hydrolysis products, did not display adverse effects sufficient to compromise human health

Finn \& Lord (2000) addressed the possible neurotoxicity induced by the utilization of sucralose, its hydrolysis products and 6-chloro 6-deoxiglucose (6-CG). Given that these three products possess similarities in their structures, it is appropriate to verify the neurotoxicity in species susceptible to 6-CG - proven to be neurotoxic. Sucralose and its hydrolysis products were administered to rats and monkeys at the dose of $1000 \mathrm{mg} / \mathrm{kg}$ body weight/ day, for 21 and 28 days, for subsequent analysis by electron or light microscope of histopathological structure and possible effects in the CNS ultrastructure of male rats, female rats and male monkeys. This study did not evidence alterations in the central nervous system induced by sucralose and its hydrolysis product, 4-CG. Given the impossibility of sucralose being metabolized to 6-CG, a neurotoxicity similar to 6-CG should not be expected.

In the same study, as positive control, 6-chloro 6deoxiglucose was administered by gavage at the dose of 500 $\mathrm{mg} / \mathrm{kg}$ body weight/day, predicting that neurotoxic alterations induced (as symmetric lesions in nuclei deep in the cerebellum cerebrum and spinal medulla, and profound neurological lesions including the CNS) would be found.

The potential of formation of 6-chloro-6-deoxifrutose (6CF) starting from metabolite of sucralose hydrolysis 1-6 DCF exists theoretically. However, if it is produced, its quantity would be small and negligible. The major metabolite of 1,6 DCF does not involve the formation of 6-CF or any 
other known neurotoxic component: it consists of the formation of glutathione conjugated to 1,6 DCF, forming conjugated glutathione, with no 6-CF being produced (Houghes et al., 1989).

Goldsmith \& Meckel evaluating acute toxicity, utilized female and male mice ( $16 \mathrm{~g} / \mathrm{kg} /$ day) and male rats ( $10 \mathrm{~g} / \mathrm{kg} /$ day), administered for $4-8$ weeks, at concentrations of 1,2 and $5 \%$. No significant teratological effects were observed at doses of 1 or $2 \%$. But at $5 \%$, there was diminished food consumption, weight gain, deficient food conversion and alterations in absolute and relative weights of various organs, including the spleen and thymus, as well as histopathological alterations of the cecum. Furthermore, a diet containing $5 \%$ for 4 weeks produced diminution in the number of lymphocytes and increase in the excretion of calcium and magnesium, although these alterations were without statistical significance. However, the 5\% dose produced a significant drop in the urinary volume at both 4 and 8 weeks. It is believed that many of the effects were probably secondary to the diminished food consumption or to large-scale consumption of a non-nutritive diet, of low absorption and with osmotically active substance.

In the same study, evaluating subchronic toxicity, doses of $0,750,1500$ and $3000 \mathrm{mg} / \mathrm{Kg}$ body weight/day, were administered by gavage to male and female rats for 26 weeks, investigating the diets and their respective toxicities. The diet of $3000 \mathrm{mg} / \mathrm{Kg}$ body weight/day for 26 weeks presented increase in the relative weight of the kidney, as well as in enlargement and weight of the cecum. In this study, toxicity was not evidenced, and there was only reduced of palatability and digestibility in diets containing high concentrations of sucralose, as the cause for the decreased food consumption. Under acute administration, for 4 to 8 weeks, at concentrations of $1,2.5$ and $5 \%$, no significant toxological effects occurred at 1 and $2.5 \%$. However, the $5 \%$ concentration produced reduction of food consumption, body weight gain and weights of some organs (spleen), and histopathological alterations changes of the thymus in rats for 4 or 8 weeks.

A similar study was accomplished by Mann et al. (2000) to evaluate chronic toxicity and carcinogenic potential in Sprague Dawley rats, who were administered sucralose at doses of 0.3, 1 and 3\%, during pregnancy and in the subsequent 104 weeks. To assess chronic toxicity, rats were sacrificed at 52 weeks and 78 weeks, and to evaluate carcinogenesis, at 104 weeks. Among the effects found, at doses of $1 \%$ and $3 \%$, there occurred body weight loss from lesser food consumption due to reduction in palatability in the diet and a physiological response provoked by high sucralose concentration, not digested in the diet. In relation to non-neoplastic findings, epithelial hyperplasia of the renal pelvis was observed in all females of the treated group, mineralization of the renal pelvis in females treated with intermediate and high doses of sucralose (1\% and 3\%) and hemorrhagic degeneration in the adrenal cortex, in males and females treated with high doses of the sweetener.

According to Ono et al. (2005) and Lopes \& Drager (2006), the global population is presenting rises in overweight, obesity, diabetes, hypertension, cardiovascular diseases, hyperlipidemia and hypercholesterolemia, a situation which has created concern about changes in lifestyle and balanced diet. As a result, there is an acceleration in the use of light or diet products, and in the consequent consumption of sweeteners. Given that the use of sucralose, one of the newest sweeteners of high sweetening power, has been gradually increasing, new studies are necessary to attest to its safe consumption. Recent studies have proven an association between ingestion of sweeteners and nephrotoxicity, hepatoxicity or retardation of placental and fetal development (Arruda et al., 2003; Portela \& Azoubel, 2004; Martins et al., 2005; De Matos et al., 2006; Portela et al., 2007).

RODERO, A. B.; RODERO, L. S. \& AZOUBEL, R. Toxicidad de la sucralosa en humanos: Una revisión. Int. J. Morphol., 27(1):239$244,2009$.

RESUMEN: La sucralosa es un edulcorante artificial no nutritivo, 600 veces más dulce que la sacarosa, y es muy estable a altas temperaturas, entre otras características. Fue aprobado por la FDA, en 1999, para ser utilizada en los alimentos, bebidas, productos farmacéuticos, dietéticos y suplementos vitamínicos. Los estudios sugieren una difusión a través de la barrera placentaria, de pequeñas dosis de la sucralosa y sus metabolitos. Sus productos de hidrólisis (4-CG e 1,6-DCF) se absorben más rápidamente que la sucralosa: 4CG se excreta intacta en la orina, y el 1,6-DCF sufre reducción con la eliminación por la orina o la rápida conjugación con glutatión. Diversos órganos pueden verse afectados por la ingestión de altas dosis de sucralosa. Como resultado del aumento en el consumo mundial de los edulcorantes y productos de tipo light o diet, son necesarias investigaciones para evaluar la acción de esta sustancia en la especie humana. El presente estudio tiene como objetivo realizar una revisión de la literatura que trata de las indicaciones de uso, la farmacodinamia, así como los potencialidades cancerígenas, teratogénicas, neurotóxicas y nefrotóxicas de la sucralosa.

PALABRAS CLAVE: Sucralosa; Edulcorante; Toxicología. 


\section{REFERENCES}

Arruda, J. G. F.; Martins, A. T. \& Azoubel, R. Ciclamato de sódio e rim fetal. Rev. Bras. Saúde Matern. Infant., 3(2):147-50, 2003.

Barndt, R. L. \& Jackson, G. Stability of sucralose in baked goods. Food Technol., 44(1):62-6,1990.

Binns, N. M. Sucralose: Alt sweeteners and light. Nutr. Bull. BNF., 29(1):53-8, 2003.

Campos, M. B. Aplicação de sucralose em iogurtes e preparados de frutas para iogurtes. Food Ingredients, 19:68$71,2002$.

Campos, M. B. Sucralose: a revolução em adoçantes. Food Ingredients, 17:18-21, 2000.

Candido, L. M. B. \& Campos, A. M. Alimentos para fins especiais: dietéticos. São Paulo, Livraria Varela, 1995. p.423

De Matos, M. A.; Martins, A. T. \& Azoubel, R. Efectos del ciclamato de sodio en la placenta de rata: estudio morfométrico. Int. J. Morphol., 24(2):137-42, 2006.

Department of Health and Human Services. Food and Drug Administration. Food additives permitted for direct addition to food for human consumption; Sucralose. 21 CFR Part 172 [Docket nº 99F-0001]. Federal Register, 64(155):43908, 1999

Finn, J. P. \& Lord, G. H. Neurotoxicity studies on sucralose and its hydrolysis products with special reference to histopathologic and ultrastructural changes. Food Chem. Toxicol., 38(2): S7-17, 2000

Frank, G. Sucralose: An overview. Undergraduate Res. J. Hum. Sciences (URC), 1:1-13, 2002.

Goldsmith, L. A. \& Meckel, C. M. Sucralose. In: Nabors, L. O’B. \& Gelardi, R. C. Edit. Alternative sweeteners. 3. ed. New York, Marcel Dekker, 2001. pp.185-207.

Grice, H. C. \& Goldsmith, L. A. Sucralose: an overview of the toxicity data. Food Chem. Toxicol., 38(2):S1-6, 2000.

Houghes, H. M.; Powell, G. M.; Snodin, D. J.; Daniel, J. W.; Crawford, A.; Sanders, J. K. \& Curtis, C. G. Glutathionedependent dechlorination of 1,6-dichloro-1,6dideoxyfructose. Biochem. J., 259(2):537-43, 1989.
John, B. A.; Wood, S. G. \& Hawkins, D. R. The pharmacokinetics and metabolism of sucralose in the rabbit. Food Chem. Toxicol., 38(2):S111-3, 2000.

Kille, J. W.; Tesh, J. M.; McAnulty, P. A.; Ross, F. W.; Willoughby, C. R.; Bailey, G. P.; Wilby, O. K. \& Tesh, S. A. Sucralose: Assessment of teratogenic potential in the rat and rabbit. Food Chem. Toxicol., 38(2):S43-52, 2000.

Knight I. The development and applications of sucralose, a new high-intensity sweetener. Can. J. Physiol. Pharmacol., 72(4):435-9, 1994.

Lopes, H. F. \& Drager, L. F. Doenças cardiovasculares: obesidade e síndrome metabólica. In: Lopes, A. C. Edit. Tratado de clínica médica. São Paulo, Roca, 2006. pp.71227.

Lord, G. H. \& Newberne, P. M. Renal mineralization: A ubiquitous lesions in chronic rat studies. Food Chem. Toxicol., 28(8):449-55, 1990.

Mandel, L. D. \& Grotz, V. L. Dental considerations in sucralose use. J. Clin. Dent., 13(3):116-8, 2002.

Mann, S. W.; Yuschak, M. M.; Amyes, S. J.; Aughton, P. \& Finn, J. P. A combined chronic toxicity/carcinogenicity study of sucralose in Sprague-Dawley rats. Food Chem. Toxicol., 38(2):S71-89, 2000.

Martins, A. T.; Azoubel, R.; Lopes, R. A.; Di Matteo, M. A. S. \& Arruda, J. G. F. Efectos del ciclamato de sódio en el hígado fetal de ratas: Estudios cariométrico y estereológico. Int J Morphol., 23(3):221-6, 2005.

McNeil Nutritionals. Splenda® Brand Sweetener: A guide for healthcare professionals. Washington, McNeil Nutritionals, 2006.

McNeil Specialty Products. Food Additive Petition 7A3987: Sucralose. Washington, McNeil Specialty Products, 1987.

Ono, T.; Guthold, R. \& Strong, K. WHO Global comparable estimates. Genebra, WHO, 2005.

Ophardt, C. E. Virtual Chembook, Department of Chemistry, Elmhurst, IL., Elmhurst College, 2003.

Pachione, R. Indústria do diet engorda as vendas. Rev. Quím. Derivados., 419(1):38-50, 2003. 
Portela, G. S. \& Azoubel, R. Nefrotoxicidade fetal com o uso da amicacina. Estudo cariométrico. J. Bras. Nefrol., 26(1):12-8, 2004.

Portela, G. S.; Azoubel, R. \& Batigália, F. Effects of aspartame on maternal-fetal and placental weights, lenght of umbilical cord and fetal liver: a kariometric experimental study. Int. J. Morphol., 25(3):549-54, 2007.

Roberts, A.; Renwick, A. G., Sims, J. \& Snodin, D. J. Sucralose metabolism and pharmacokinetics in man. Food Chem. Toxicol., 38(2):S31-41, 2000.

Sham, W. S. Splenda: A safe and sweet alternative to sugar. Nutr. Bites., 10(2):1-5, 2005.

Sims, J.; Roberts, A.; Daniel, J. W. \& Renwick, A. G. The metabolic fate of sucralose in rats. Food Chem. Toxicol., 38(2):S115-21, 2000.

Whitmore, A. FDA approves new high-intensity sweeteners sucralose. FDA Talk, 16, 1998.

Wood, S. G.; John, B. A. \& Hawkins, D. R. The pharmacokinetics and metabolism of sucralose in the dog. Food Chem. Toxicol., 38(Suppl 2):S99-106, 2000.
Correspondence to: Ademir Barianni Rodero

Unicastelo - Universidade Camilo Castelo Branco

University, School of Health Sciences

Fernandópolis - SP

Av. Projetada, $s / n$

Zip Code - 15600-000

Fernandópolis - SP

BRAZIL

Email: coordgeralmedicina@unicastelo.br

Received: 01-07-2008

Accepted: 04-10-2008 